\title{
Prolactin as a factor in the uterine response to progesterone in rabbits
}

\author{
J. C. Daniel, Jr, Amy E. Jetton* and Beverly S. Chilton $\dagger$ \\ Department of Zoology, University of Tennessee, Knoxville, TN 37996 and $\dagger$ Department of \\ Anatomy, Medical University of South Carolina, Charleston, SC 29425, U.S.A.
}

\begin{abstract}
Summary. The direct effect of prolactin on uteroglobin production and on uterine endometrial oestrogen and progesterone receptor concentrations was tested by using ovariectomized rabbits (at least 12 weeks) treated with prolactin; prolactin + progesterone; prolactin + oestradiol + progesterone; oestradiol + progesterone; or progesterone alone. Prolactin treatment produced a significant $(P<0.05)$ increase in the concentration of cytosolic oestrogen and progesterone receptors, restoring the concentrations to values found at oestrus. However, the concentration of nuclear receptors remained low. In the remaining treatment categories there was no significant $(P>0.05)$ increase in the concentration of oestrogen and progesterone receptors compared with those in ovariectomized controls. However, the sequential treatment of ovariectomized animals with prolactin + progesterone stimulated uteroglobin production to a concentration equal to that found in intact rabbits on the 5 th day of pregnancy. This was not achieved by prolactin or progesterone alone or with oestradiol. These results suggest that prolactin acts as an essential factor in the rabbit uterine response to progesterone, perhaps by the modulation of progesterone receptor activity.
\end{abstract}

\section{Introduction}

Administration of progesterone to rabbits which have been ovariectomized for 3 days to 4 weeks will induce synthesis of the uterine protein uteroglobin by the endometrium (Urzua, Stambaugh, Flickinger \& Mastroianni, 1970; Arthur \& Daniel, 1972; Bullock \& Willen, 1974; Rahman, Billiar \& Little, 1975; Fridlanski \& Milgrom, 1976). Daniel (1980) reported that after ovariectomy the endometrium became progressively more refractory to ovarian steroids given at normally effective concentrations and by 12 weeks after ovariectomy normal levels of uteroglobin synthesis could not be elicited by any protocol tested for oestrogen and/or progesterone administration. However, the uterine fluids of animals given extracts of whole brain followed by oestrogen and progesterone had a small, but distinct uteroglobin component. When whole brain was divided into three parts, namely pineal region, pituitary-hypothalamic tissue, and the rest of the brain, extracts made of the pituitary-hypothalamus also elicited uteroglobin production in progesterone-treated animals (J. C. Daniel, unpublished). When Martinet, Allais \& Allain (1981) identified the role of prolactin in blastocyst growth, luteal function and pregnancy length in mink, and Murphy, Concannon, Travis \& Hansel (1981) showed that prolactin terminated the delay of implantation in mink, we were encouraged to test the effect of prolactin on the production of uteroglobin.

A direct effect of prolactin on the uterus has been proposed by Leung \& Sasaki (1973) and Joseph \& Mubako (1975). However, Saiduddin \& Zassenhaus (1977) were unable to demonstrate any effect of prolactin on oestrogen receptor binding in the uteri of ovariectomized rats. Sartor, Slabaugh, Sakai \& Gorski (1983) demonstrated that prolactin does not control the developmental

* Present address: Department of Anatomy, Monash University, Clayton, Melbourne, Victoria 3168, Australia. 
increase in uterine oestrogen receptor in young mice. In contrast, Danforth, Tamarkin, Do \& Lippman (1983) have suggested that melatonin, a pineal indolamine, regulates increased uterine growth and metabolism in the hamster by increasing the oestrogen receptor concentration. Melatonin is also known to increase the concentration of oestrogen receptor in MCF-7 human breast cancer cells (Danforth, Tamarkin \& Lippman, 1981). We therefore determined the effect of prolactin on steroid hormone receptor concentrations in the rabbit uterine endometrium.

\section{Materials and Methods}

Reagents and buffers. Reagents were purchased from the following sources: $\left[6,7-{ }^{3} \mathrm{H}(\mathrm{N})\right]-$ oestradiol (sp. act. $52 \cdot 0 \mathrm{Ci} / \mathrm{mmol}), 17 \beta$-methyl- $\left[{ }^{3} \mathrm{H}\right]$ promegestone $(17,21$-dimethyl-19-nor-pregna4,9-diene-3,20-dione; $\left[{ }^{3} \mathrm{H}\right] \mathrm{R} 5020 ; \mathrm{sp}$. act. $\left.87.0 \mathrm{Ci} / \mathrm{mmol}\right)$ and radioinert R5020 from New England Nuclear Corp. (Boston, MA); diethylstilboestrol, calf thymus DNA, ovine prolactin, oestrogen and progesterone from Sigma Chemical Co. (St Louis, MO); Ready-Solv EP scintillation cocktail from Beckman Instruments, Inc. (Fullerton, CA); Tissue Culture Medium 199 from Gibco (Grand Island, NY); DNA grade Bio-Gel HTP hydroxylapatite from Bi-Rad Laboratories (Richmond, CA); Spectra/Por 3 dialysis tubing from Fisher Scientific (Atlanta, GA); and aquacide 1A from Calbiochem-Behring (San Diego, CA). All other chemicals purchased were of standard reagent grade.

Tris- $\mathrm{HCl}$ buffers, $\mathrm{pH} 7 \cdot 5(\mathrm{~T})$, containing potassium chloride $(\mathrm{K})$, or disodium ethylenediamine tetraacetic acid $(\mathrm{E})$, or monothioglycerol $(\mathrm{M})$ were designated according to the millimolarity of their components, i.e. $\mathrm{T}_{50} \mathrm{E}_{1} \mathrm{M}_{12}=50 \mathrm{~mm}$-Tris- $\mathrm{HCl} / 1 \mathrm{~mm}$-disodium ethylenediamine tetraacetic acid/12 mM-monothioglycerol. Glycerol was added on a $\mathrm{v} / \mathrm{v}$ basis. Hydroxylapatite slurry (wet hydroxylapatite : buffer $1: 1 \mathrm{v} / \mathrm{v}, \mathrm{pH} 7 \cdot 4)$ was prepared according to Garola \& McGuire (1977, 1978).

Animal treatment. Adult $(3.6-4.5 \mathrm{~kg})$ virgin New Zealand White rabbits were housed individually for 3 weeks before experimentation. These rabbits were used at oestrus, as verified by a reddish-purple vulva and lordosis behaviour, directly for experimentation $(N=17)$, for mating and use as 5-day pregnant controls $(\mathrm{N}=6)$, or ovariectomized through a mid-ventral incision. After a minimum of 12 weeks after ovariectomy, 8 animals were used as experimental controls, i.e. injected with corn oil ( $1 \mathrm{ml} / 24 \mathrm{~h}$ for 5 days), the vehicle for steroid hormone administration. The remaining ovariectomized animals were divided into 5 treatment groups (4-8 animals/group). In Group 1, rabbits received subcutaneous injections of prolactin in phosphate-buffered saline $(\mathrm{pH}$ $7 \cdot 2$ ) every $24 \mathrm{~h}$ for 5 days. In studies in which uteroglobin was measured, animals received $1.0 \mathrm{mg}$ prolactin daily; in those in which receptor concentrations were measured, animals received $0.5 \mathrm{mg}$ prolactin daily. In Group 2, the rabbits were treated with prolactin for 5 days followed by progesterone ( $3 \mathrm{mg} / \mathrm{kg} / 24 \mathrm{~h}$ ) for 4 days. In Group 3, rabbits were treated with progesterone alone for 4 days. In Group 4, rabbits were treated sequentially with prolactin for 5 days, oestradiol (100 $\mu \mathrm{g} / \mathrm{kg} / 24 \mathrm{~h}$ ) for 3 days, and progesterone for 4 days. In Group 5, rabbits were treated with oestradiol for 3 days, and progesterone for 4 days.

Uterine fluid collection and analysis. Uterine fluid samples were collected $6 \mathrm{~h}$ after the last injection, by flushing both horns of the uterus from oviducal to cervical end with $10 \mathrm{ml}$ phosphatebuffered saline solution, $\mathrm{pH} 7 \cdot 2$. These samples were dialysed in Spectra Por 3 for $24 \mathrm{~h}$ against two changes of distilled water and then concentrated in Aquacide 1A down to 0.5-1.0 ml volume. The microbiuret method described by Itzhaki \& Gill (1964) was used to determine the total protein concentration of each sample.

The proteins of each sample were separated by polyacrylamide gel slab electrophoresis (PAGE) using a Biorad Laboratories Model 220 dual slab gel system and a Model 500 power supply: $1 \mathrm{~cm}$ of $4 \frac{1}{2} \%$ acrylamide Tris-sulphate stacking gel and $8.5 \mathrm{~cm} 8 \%$ running gel were used. Equal amounts of 
protein $(200 \mu \mathrm{g})$ in each well were run through the stacking gel at a constant $200 \mathrm{~V}(30-45 \mathrm{~min})$ and through the running gel at a constant $100 \mathrm{~V}(5-6 \mathrm{~h})$. A tracking dye, bromophenol blue, was added to the samples and/or the upper tank buffer, and electrophoresis was stopped when the dye line was $0.5 \mathrm{~cm}$ from the bottom of the gel. Gels were stained with $0.1 \%$ amido black in $10 \%$ acetic acid, and destained with $10 \%$ acetic acid.

Simple one-dimensional immunodiffusion with a single antibody-antigen system in tubes as described by Oudin (1952) was used to determine the uteroglobin concentration of each sample. In this sytem the speed with which a precipitation line moves through an agarose gel containing the antibody, in an Oudin's tube, is constant according to the concentration of the antigen and of the antibody until antigen or antibody exhaustion. The distance of the precipitation line from the antigen sample gives a value, $h$. The $h$ value plotted opposite the square root of the time of the reading gives a straight line of slope $k=h / \sqrt{\mathrm{t}}$. This $\mathrm{k}$ value is a constant for a given antigen concentration provided that the antibody concentration remains constant.

For the antibody in the Oudin method we used a goat anti-uteroglobin, supplied to us by $\mathrm{Dr}$ David Bullock of Baylor College of Medicine (Bullock, Woo \& O'Malley, 1976). The specificity of the antiserum for uteroglobin was verified by the absence of immunoprecipitation bands when the antiserum was exposed (radial immunodiffusion) to rabbit serum and to uterine flushings from oestrous rabbits. Uteroglobin for use as an antigen standard was collected from pooled uterine flushings of four 5-day pregnant rabbits. After concentration, these flushings were fractionated by Sephadex G-200 gel filtration. An elution profile was obtained with a protein assay by the method of Lowry, Rosebrough, Farr \& Randall (1951) and by absorption at $280 \mathrm{~nm}$. The fractions of the uteroglobin peak were pooled and concentrated, and Sephadex G-50 gel filtration was used in a similar manner to purify the sample further as described by Popp, Foresman, Wise \& Daniel (1978). PAGE was used to check the homogeneity of this sample.

Glass tubing (i.d. $3 \mathrm{~mm}$ ) was cut into $5-\mathrm{cm}$ lengths and sealed at one end. These tubes were precoated with $0.5 \%$ agarose in glass-distilled water by pipetting the hot agarose in and out of the tube and shaking the tube to remove excess agarose. After drying, these tubes were filled threequarters full with a $0.5 \%$ agarose gel containing anti-uteroglobin serum at $1: 5$ dilution. A layer of mineral oil was placed on top of this gel to prevent it drying. The tubes were inoculated with $30-50$ $\mu l$ protein samples, and the time of inoculation was recorded. Readings and times for $h$ values were recorded every few hours until 4 readings were obtained, and then they were used to calculate $k$ values. Uteroglobin concentrations were determined by comparing the $\mathrm{k}$ values to a standard curve $(r=0.93)$ prepared from different concentrations of purified uteroglobin.

The data were analysed statistically by one-way ANOVA and Student-Newman-Keuls (SNK) tests. Significance was tested at levels of 0.05 and 0.01 for the ANOVA and at 0.05 for the SNK tests.

Tissue preparation for receptor assays. Uterine endometrium was scraped from underlying myometrium using a scalpel blade, weighed and homogenized $(100 \mathrm{mg} / \mathrm{ml})$ in ice-cold Medium $\mathrm{T}_{50} \mathrm{E}_{1} \mathbf{M}_{12}$, containing $30 \%$ glycerol, with a Polytron Pt-10 homogenizer (Brinkman Instruments, Westbury, NY). As verified by light microscopy, tissue homogenates contained cellular debris and intact nuclei. All subsequent steps were conducted at $4^{\circ} \mathrm{C}$. Samples of $100 \mu l$ were reserved for DNA assay. Tissue homogenates were centrifuged at $1200 \mathrm{~g}$ for $20 \mathrm{~min}$ to obtain nuclear fractions. Further processing of pelleted nuclear material is described below. Supernatant fractions were centrifuged at $40000 \mathrm{~g}$ for $40 \mathrm{~min}$ to yield cytosol fractions which were assayed for total oestrogen and progesterone receptor concentrations.

Extraction of nuclear receptor. The methodology of Chen \& Leavitt (1979) and Evans, Chen, Henry \& Leavitt (1980) was used as modified by Chilton, Nicosia \& Lyttle (1982) and Chilton \& Key (1984). Briefly, the nuclear pellet was washed twice by resuspension in Medium $\mathbf{T}_{10}$ containing $10 \%$ glycerol and centrifuged at $1200 \mathrm{~g}$ for $10 \mathrm{~min}$. The nuclear pellet was resuspended in Medium $\mathrm{T}_{50} \mathrm{E}_{1} \mathrm{M}_{12} \mathrm{~K}_{500}$ containing $30 \%$ glycerol and uniformly dispersed during the 2 -h extraction. 
Nuclear debris was removed by centrifugation at $40000 \mathrm{~g}$ for $30 \mathrm{~min}$. The nuclear extract (supernatant) was assayed for nuclear oestrogen and progesterone receptor content.

Receptor assays. We have previously (Chilton et al., 1982; Chilton \& Key, 1984) used the method of Holt, Lorincz \& Lyttle (1981) for adsorbing receptor to hydroxylapatite. Briefly, $200 \mu l$ cytosol or nuclear extract were incubated in tubes containing $250 \mu$ l hydroxylapatite slurry for 15 min, with gentle agitation every $5 \mathrm{~min}$. Suspensions were centrifuged at $500 \mathrm{~g}$ for $3 \mathrm{~min}$. Supernatants were discarded and receptor concentrations were measured by Scatchard analysis (1949) of specific binding data. Pellets were included in $500 \mu \mathrm{l}$ Medium $\mathbf{T}_{10} \mathbf{E}_{1} \mathbf{M}_{12}$ containing increasing concentrations $(0.5-20.0 \mathrm{nM})$ of $\left[{ }^{3} \mathrm{H}\right]$ oestradiol or $\left[{ }^{3} \mathrm{H}\right] \mathrm{R} 5020$. Parallel samples were incubated with 100 -fold excess of diethystilboestrol or radioinert $\mathrm{R} 5020$ for evaluation of nonspecific binding of radioactive ligand. Samples were incubated at $30^{\circ} \mathrm{C}$ for $3 \mathrm{~h}$ to measure total oestrogen receptor and at $4^{\circ} \mathrm{C}$ for $18-20 \mathrm{~h}$ to measure total progesterone receptor as previously described (Chilton et al., 1982). Having established optimal conditions we then used a single saturating dose assay (Chilton \& Key, 1984). Pellets were incubated as described above with a final concentration of $20 \cdot 0 \mathrm{nM}-\left[{ }^{3} \mathrm{H}\right]$ oestradiol $\pm 2 \cdot 0 \mu \mathrm{M}$-diethystilboestrol or $20 \cdot 0 \mathrm{nM}-\left[{ }^{3} \mathrm{H}\right] \mathrm{R} 5020 \pm 2 \cdot 0$ $\mu \mathrm{M}$-radioinert R5020.

After incubation, the pellets were washed twice with $3 \mathrm{ml}$ Tris-phosphate buffer $(50 \mathrm{mM}$-Tris-

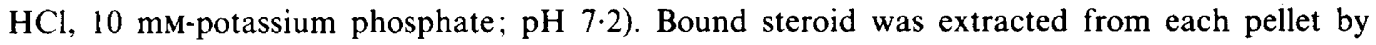
incubation in $1.0 \mathrm{ml}$ ethanol at room temperature for $30 \mathrm{~min}$, with gentle agitation every $5-10 \mathrm{~min}$. Radioactivity was quantitated in $4 \mathrm{ml}$ scintillation cocktail. For analysis of receptor data standard parametric statistics and Student's $t$ test were used.

Radioimmunoassay for progesterone. Blood samples were collected via a cannula inserted into the central ear vein. All blood samples were allowed to clot at $4^{\circ} \mathrm{C}$ for $20-30 \mathrm{~min}$. Sera were collected and stored frozen $\left(-20^{\circ} \mathrm{C}\right)$ for steroid assay. Thawed samples were extracted with spectral grade $n$ hexane. Progesterone concentrations were measured by radioimmunoassay (Mathur, Landgrebe \& Williamson, 1980), the sensitivity of which was $0.1 \mathrm{ng} / \mathrm{ml}$ and the percentage recovery of $\left[{ }^{3} \mathrm{H}\right]$ progesterone in the total assay was $98 \%$. The degree of cross-reactivity of the antiserum was $<1 \%$ with $17 \alpha$-hydroxyprogesterone.

DNA analysis. The procedure of Burton (1956) was used to determine DNA content using calf thymus DNA as the standard.

\section{Results}

The collective results for uterine fluids from the animals in all treatment groups are presented in Table 1. Although some individual divergence is apparent in a few of the experimental categories, these results clearly show that treatment with prolactin + progesterone supports reliable production of uteroglobin by long-term ovariectomized does, at levels equal to those found in 5-day pregnant animals. This result was not produced by any of the other treatments. Progesterone alone stimulated very low levels of uteroglobin production but prolactin alone had almost no measurable effect. Oestradiol, administered with progesterone, sustained some uteroglobin production but when administered in sequence between prolactin and progesterone counteracted the effect the other two had without the oestrogen.

Scatchard analysis of $\left[{ }^{3} \mathrm{H}\right]$ oestradiol binding data indicated a $K_{\mathrm{d}}=17.0 \pm 0.5 \times 10^{-9} \mathrm{M}$ $(r=0.98)$ for cytosol fractions, and a $K_{\mathrm{d}}=2 \cdot 1 \pm 0.1 \times 10^{-9} \mathrm{M}(r=0.98)$ for KCl-extracted nuclear fractions from endometrium of oestrous controls. The specific binding (mean \pm s.e.m.) was $13.0 \pm 1.4 \mathrm{pmol} / \mathrm{mg}$ DNA for cytosol, with $10 \%$ of the total receptor retained in the nuclear fraction $(1.4 \pm 0.1 \mathrm{pmol} / \mathrm{mg} \mathrm{DNA})$. As shown in Table 2 , ovariectomy resulted in a $30 \%$ reduction in the concentration of cytosol and nuclear oestrogen receptors. Scatchard analysis of $\left[{ }^{3} \mathrm{H}\right] \mathrm{R} 5020$ binding 
Table 1. Hormonal effects on uteroglobin secretion in the uteri of long-term ovariectomized rabbits

\begin{tabular}{|c|c|c|c|c|}
\hline \multirow[b]{2}{*}{ Group } & \multirow{2}{*}{$\begin{array}{l}\text { Treatment } \\
\text { (see text for details) }\end{array}$} & \multirow{2}{*}{$\begin{array}{l}\text { Uteroglobin band } \\
\text { detectable by PAGE }\end{array}$} & \multicolumn{2}{|c|}{$\begin{array}{l}\text { \% Uteroglobin by Oudin } \\
\text { immunodiffusion method } \\
\text { ( } \mathrm{mg} / \mathrm{mg} \text { protein) }\end{array}$} \\
\hline & & & Individual values & Mean \pm s.e.m. \\
\hline Control & Pregnant & $\begin{array}{l}+ \\
+ \\
+ \\
+ \\
+ \\
+\end{array}$ & $\begin{array}{l}47 \\
69 \\
95 \\
67 \\
43 \\
47\end{array}$ & $61 \cdot 3 \pm 8 \cdot 3^{b}$ \\
\hline 1 & $\begin{array}{l}\text { Ovariectomized, prolactin } \\
\text { alone }\end{array}$ & $\begin{array}{l}- \\
- \\
- \\
-\end{array}$ & $\begin{array}{l}0 \\
0 \\
0 \\
5 \cdot 5\end{array}$ & $1 \cdot 4 \pm 1 \cdot 4^{a}$ \\
\hline 2 & $\begin{array}{l}\text { Ovariectomized, } \\
\text { prolactin + progesterone }\end{array}$ & $\begin{array}{l}+ \\
+ \\
+ \\
+\end{array}$ & $\begin{array}{l}78 \\
59 \\
64 \\
48\end{array}$ & $62 \cdot 3 \pm 6 \cdot 2^{b}$ \\
\hline 3 & $\begin{array}{l}\text { Ovariectomized, } \\
\text { progesterone alone }\end{array}$ & $\begin{array}{l}\text { Trace } \\
\text { Trace } \\
- \\
-\end{array}$ & $\begin{array}{l}24 \\
20 \\
6 \cdot 7 \\
6 \cdot 4\end{array}$ & $14 \cdot 3 \pm 4 \cdot 6^{a}$ \\
\hline 4 & $\begin{array}{l}\text { Ovariectomized, } \\
\text { prolactin }+ \text { oestradiol }+ \\
\text { progesterone }\end{array}$ & $\begin{array}{c}- \\
\text { Trace } \\
- \\
+\end{array}$ & $\begin{array}{c}6 \cdot 4 \\
13 \cdot 6 \\
0 \\
63 \cdot 0^{*}\end{array}$ & $6 \cdot 7 \pm 3 \cdot 9^{a}$ \\
\hline 5 & $\begin{array}{l}\text { Ovariectomized, } \\
\text { oestradiol + progesterone }\end{array}$ & $\begin{array}{c}- \\
- \\
- \\
\text { Trace }\end{array}$ & $\begin{array}{l}0 \\
5 \cdot 5 \\
0 \\
30\end{array}$ & $8 \cdot 9 \pm 7 \cdot 2^{a}$ \\
\hline
\end{tabular}

* Ovarian remnant found in this animal. Not included in mean calculations.

Values with different superscript letters are significantly different, $P<0.01$ (ANOVA) and $P<0.05$ (StudentNewman-Keuls).

Table 2. Oestrogen and progesterone receptor concentrations and corresponding of serum progesterone concentrations for rabbits in all treatment groups

\begin{tabular}{|c|c|c|c|c|c|c|}
\hline \multirow[b]{2}{*}{ Treatment } & \multirow{2}{*}{$\begin{array}{l}\text { No. of } \\
\text { animals }\end{array}$} & \multirow{2}{*}{$\begin{array}{l}\text { Serum progesterone } \\
(\mathrm{ng} / \mathrm{ml})\end{array}$} & \multicolumn{2}{|c|}{$\begin{array}{l}\text { Oestrogen receptor } \\
\text { conc. (pmol/mg DNA) }\end{array}$} & \multicolumn{2}{|c|}{$\begin{array}{l}\text { Progesterone receptor } \\
\text { conc. (pmol/mg DNA) }\end{array}$} \\
\hline & & & Cytosolic & Nuclear & Cytosolic & Nuclear \\
\hline Oestrous, control & 17 & $1.44 \pm 0.7$ & $13 \cdot 0 \pm 1 \cdot 4$ & $1 \cdot 4 \pm 0 \cdot 1$ & $18 \cdot 0 \pm 1 \cdot 3$ & $2.9 \pm 0.6$ \\
\hline $\mathrm{OVX}^{*}$, control & 8 & $0.71 \pm 0.17$ & $9.5 \pm 0.8$ & $1 \cdot 0 \pm 0 \cdot 1$ & $4 \cdot 3 \pm 1 \cdot 1$ & $0.6 \pm 0.1$ \\
\hline $\mathrm{OVX}+$ prolactin & 8 & $0.49 \pm 0.06$ & $20.4 \pm 3.5$ & $1 \cdot 3 \pm 0 \cdot 1$ & $13 \cdot 1 \pm 2 \cdot 7$ & $0.4 \pm 0.1$ \\
\hline $\begin{array}{l}\text { OVX + prolactin }+ \\
\text { progesterone }\end{array}$ & 4 & $22 \cdot 9 \pm 5 \cdot 22$ & $6.9 \pm 2 \cdot 7$ & $1 \cdot 1 \pm 0.4$ & $7 \cdot 7 \pm 2 \cdot 2$ & $0 \cdot 8 \pm 0 \cdot 3$ \\
\hline OVX + progesterone & 4 & $43 \cdot 2 \pm 6 \cdot 54$ & $7 \cdot 3 \pm 3 \cdot 0$ & $1 \cdot 1 \pm 0 \cdot 4$ & $6.0 \pm 1.8$ & $1 \cdot 2 \pm 0 \cdot 4$ \\
\hline $\begin{array}{l}\text { OVX + prolactin }+ \\
\text { oestradiol + progesterone }\end{array}$ & 6 & $33 \cdot 5 \pm 4 \cdot 56$ & $8 \cdot 0 \pm 1 \cdot 6$ & $1 \cdot 0 \pm 0 \cdot 2$ & $6 \cdot 8 \pm 1 \cdot 1$ & $0.5 \pm 0.1$ \\
\hline
\end{tabular}

Values are mean \pm s.e.m.

* OVX $=$ ovariectomized for at least 12 weeks.

data from the same oestrous animals indicated a $K_{\mathrm{d}}=14.3 \pm 0.5 \times 10^{-9} \mathrm{M}(r=0.96)$ for cytosol fractions, and a $K_{\mathrm{d}}=1.5 \pm 0.02 \times 10^{-9} \mathrm{M}(r=0.98)$ for $\mathrm{KCl}$-extracted nuclear fractions. The specific binding was $18.0 \pm 1.3 \mathrm{pmol} / \mathrm{mg}$ DNA for cytosol, with $14 \%$ of the total receptor retained 
in the nuclear fraction $(2.9 \pm 0.6 \mathrm{pmol} / \mathrm{mg}$ DNA). Ovariectomy resulted in a significant $(P$ $<0.05$ ) decrease in the concentration of cytosolic and nuclear progesterone receptors (Table 2). Prolactin treatment produced a significant increase $(P<0.05)$ in the concentration of cytosolic oestrogen and progesterone receptors, restoring the concentrations to the values found at oestrus. However, the concentration of nuclear receptors remained low. In all other treatment categories, the concentration of oestrogen or progesterone receptors was not significantly $(P>0.05)$ different from those of ovariectomized controls. As shown in Table 2, animals were either treated with progesterone alone or progesterone was the last hormone in the injection sequence which resulted in the down regulation of both oestrogen and progesterone receptor systems.

\section{Discussion}

In addition to its mammotrophic, lactogenic and luteotrophic roles, prolactin is also known to influence the secretory activity of testicular androgens and adrenal progesterone, and to exercise some regulatory control over $\mathrm{LH}$ and $\mathrm{FSH}$, thereby increasing uterine sensitivity to oestrogens and ovarian sensitivity to gonadotrophins in different systems (Advis \& Alvarez, 1977; Bartke, Hafiez, Bex \& Dalterio, 1978; Martinet et al., 1981; Channing \& Evans, 1982; Advis, Aguado \& Ojeda, 1983). Williams, Hammond, Weisz \& Mortel (1978) reviewed the evidence that prolactin also acts directly on uterine tissues. Relevant to the present work they note that prolactin has been shown to promote the release of uterine fluid after oestrogen treatment (Kennedy \& Armstrong, 1972), to accelerate oestradiol binding to uterine tissue (Leung \& Sasaki, 1973) and to enhance progesterone metabolism by uterine homogenates (Armstrong \& King, 1971). The mechanisms for some of these responses have been presumed to relate to changes in dopamine receptors or gonadotrophinreleasing factors.

At the dosages and injection schedules used in these studies neither prolactin nor progesterone alone induced uteroglobin synthesis in rabbits ovariectomized for 12 weeks. Conversely, Elger \& Beier (1982) reported the synthesis of uteroglobin after an ovariectomy interval of 17 months in does given $10 \mathrm{mg}$ progesterone daily for 7 days, or 1 massive dose (125 mg) of $17 \alpha$-hydroxyprogesterone caproate. The maximum amount of progesterone we gave to any single animal was $\sim 50 \mathrm{mg}$ over a 4 -day period, compared to $70 \mathrm{mg}$ over a 7 -day period given by Elger \& Beier (1982). Clearly, the daily doses in the 2 protocols are similar so the main difference lies in the length of the period of administration. However, we have been unable to elicit uteroglobin synthesis in longterm ovariectomized does after doubling the duration of exposure (i.e. $3 \mathrm{mg} / \mathrm{kg} / 24 \mathrm{~h}$ for 8 days) (unpublished data). The reasons for these differences in results are unknown.

How prolactin influences or restores the uterine response to progesterone in long-term ovariectomized rabbits is also unclear. High-affinity binding sites for prolactin exist in the uteri of a variety of mammals, including rabbits (Posner, Kelly, Shiu \& Friesen, 1974; Williams et al., 1978; Rose, Stormshak, Adair \& Oldfield, 1983), so some normal target organ function is probable. Alternatively, prolactin may increase uteroglobin production through the modulation of progesterone receptor activity.

The $K_{\mathrm{d}}$ values for nuclear oestrogen and progesterone receptors are comparable to values previously reported by Young, Smith \& Bullock (1981). Using the same assay, the $K_{\mathrm{d}}$ values for cytosolic oestrogen and progesterone receptors are slightly higher than values reported for rabbit uterine endometrium (Young et al., 1981; Neulen, Beato \& Beier, 1982). This finding is difficult to reconcile as our assay conditions, using $\left[{ }^{3} \mathrm{H}\right] \mathrm{R} 5020$ as the ligand, do not differ significantly from those of Young et al. (1981) or Neulen et al. (1982). Neither of these groups measured progesterone receptor concentrations in the presence of excess glucocorticoid, and as we have previously demonstrated (Chilton et al., 1982) that deoxycorticosterone does not compete to any extent for the oestrogen receptor we are reluctant to suggest that our results may have been affected by endogenous glucorticoids. It is possible that the progesterone receptor results were affected by variations in the tissue content of endogenous progesterone (Young et al., 1981). However, when 
the average cytosolic progesterone receptor concentration of $17.7 \pm 1.5 \mathrm{pmol} / \mathrm{mg}$ DNA was converted to molecules per cell, our value of $57500 \pm 4100$ molecules/cell for oestrous animals compared favourably with the value of $62900 \mathrm{molecules} / \mathrm{cell}$ reported by Neulen et al. (1982). Isotalo, Isomaa \& Janne (1981) reported that $\sim 12 \cdot 1 \%$ of the total progesterone receptor resides in the nuclear fraction of endometrium from young New Zealand White rabbits; while Torkkeli (1980) reported a value of $26.5 \%$. In the present study $\sim 14 \%$ of the total progesterone receptor in the endometrium of oestrous rabbits was associated with the nuclear fraction. In long-term (12 weeks) ovariectomized rabbits, the concentration of cytosolic progesterone receptor was significantly reduced $(P<0.01)$ to $4 \cdot 3 \pm 1 \cdot 1 \mathrm{pmol} / \mathrm{mg}$ DNA, or $13700 \pm 3500 \mathrm{molecules} / \mathrm{cell}$. The concentration of nuclear receptor was also reduced 5 -fold; therefore, $12 \%$ of the total progesterone receptor continues to reside in the nucleus.

The average cytosolic and nuclear oestrogen receptor concentrations in these same animals were low, despite the indications of oestrus given by a reddish or reddish-purple vulva and the presence of several mature follicles in each ovary at the time of laparotomy. Because many of these experiments were done during the summer and winter months, and because we were unable to breed many of these rabbits, we conclude that the animals may have been experiencing a seasonal dioestrus (Hartman, 1974) which is reflected in low oestrogen receptor levels.

Administration of ovine prolactin for 5 days dramatically increased the oestrogen and progesterone receptor levels above those of ovariectomized controls, effectively returning them to oestrous levels. These same conclusions would have been reached had we expressed receptor concentrations as $\mathrm{pmol} / \mathrm{mg}$ protein, because the endometrial protein : DNA ratio is about $8.4 \mu \mathrm{g}$ protein $/ \mu \mathrm{g}$ DNA for oestrous and prolactin-treated ovariectomized animals. Since both receptor assays are exchange assays, we have measured a prolactin-induced increase in total oestrogen and progesterone receptor concentrations. The low concentration of nuclear receptor in ovariectomized animals treated with prolactin compared to that of ovariectomized controls indicates that the mechanism for this induction is not simply a dynamic redistribution of receptor within cellular compartments. The increase in receptor concentrations could be the result of a general overall stimulation of cellular protein synthesis. If so, one would also expect to see an increase in uteroglobin. These data suggest that while prolactin may act directly on one or more specific cell populations to regulate steroid hormone receptors, progesterone is essential for uteroglobin synthesis and/or secretion (Daniel, Jetton \& Chilton, 1983).

The onset and progressive changes in the rate of uteroglobin secretion (Daniel \& Booher, 1977; Kao \& Bullock, 1981) parallel the changes in circulating plasma progesterone concentrations (Challis, Davies \& Ryan, 1973; Harrington \& Rothermel, 1977) during early pregnancy or pseudopregnancy in the rabbit. If prolactin is an essential factor to act synergistically with progesterone in this relationship, its serum concentration might also be expected to coincide with that of progesterone or possibly precede it slightly. As shown by McNeilly \& Friesen (1978) prolactin concentrations fluctuate fairly widely, but in general are about $15-30 \mathrm{ng} / \mathrm{ml}$ during the first 16 days of pregnancy and then drop to one-third or one-half of that level until 2-3 days before parturition at which time they rise rapidly to $150-200 \mathrm{ng} / \mathrm{ml}$. There is no obvious close correlation. However, prolactin is clearly available during the time of uteroglobin synthesis and, as McNeilly \& Friesen (1978) indicate, the amount of prolactin required would be small " . . if it played other roles during pregnancy".

A disturbing lack of agreement in several of the uterine fluid samples was seen in treatment Groups 3 and 5 for which immunodiffusion showed uteroglobin concentrations of 20,24 and $30 \%$, respectively, but polyacrylamide gel electrophoresis could only detect traces of the protein. These samples were treated no differently from the others but it may be possible that separation of the 2 subunits, polymerization, or binding of uteroglobin to some other molecule could have altered its electrophoretic mobility while still leaving antigenic sites intact and exposed. Conversely, the antiserum may have cross-reacted with another antigen in the samples, but we have no evidence for this. 
Since exogenous prolactin is necessary to restore the uterine response to progesterone in longterm ovariectomized rabbits, then endogenous prolactin must somehow have been rendered unavailable or subminimal by removal of the ovaries. The simplest explanation is found in the fact that oestrogens stimulate prolactin secretion (Kennedy \& Armstrong, 1972; McNeilly \& Friesen, 1978; Haug, 1979; Rosenfeld et al., 1983) so that removal of the ovaries would remove this source of stimulation. By this explanation, however, oestrogen supplementation, as represented by experimental Groups 4 and 5, should have restored the response. That this was not the case, indicates that some additional, and heretofore unsuspected, ovarian factor may be operational.

The lack of response in Group 5 could have resulted from the separation in time between the prolactin and progesterone administration but it may also reflect the well-documented antagonism of progesterone-induced uteroglobin synthesis seen when oestrogen is given in high dosages (e.g. Loosefelt, Fridlanski, Savouret, Atger \& Milgrom, 1981; Janne, 1981; Kopu, Kokkonen \& Janne, 1981). In this study we made no attempt to optimize the sequence or dosages for the interaction of prolactin and the steroids, but rather simply mimicked the protocols found to be effective in our earlier studies (Arthur \& Daniel, 1972; Dunbar \& Daniel, 1979; Daniel, 1980). Nevertheless, this demonstration of the effect of prolactin on the uterine secretory response to progesterone does not confer specificity on the interaction. It does not rule out other pituitary-hypothalamic hormones (e.g. growth hormone) as having a similar effect. The effect may be species specific for the rabbit, however, because prolactin is known to have different effects on the same target organs of different species. The preliminary and fragmentary nature of the evidence will not yet support formulation of a useful theory. It is concluded, however, that prolactin is an essential factor in the rabbit uterine response to progesterone, preparing the tissue for reception of progesterone which, in turn, elicits the final secretory events.

We thank Dr David Bullock for the uteroglobin antiserum; Dr M. L. Pan for consultation on the Oudin technique; Dr Thomas Chen for reviewing the manuscript; and Dr Patsy Boyce, Dr Robert Wainberg and Mr Christopher McAllister for technical assistance.

\section{References}

Advis, J.P. \& Alvarez, E.O. (1977) Changes in uterine responsiveness to estradiol in maturing female rats with precocious puberty induced by hypothalamic lesions. Biol. Reprod. 17, 321-326.

Advis, J.P., Aguado, L.I. \& Ojeda, S.R. (1983) Hyperprolactinemia enhances ovarian estrogen responsiveness to gonadotropins in prepubertal rats: antagonistic effect of adrenalectomy. Biol. Reprod. 29, 181-194.

Armstrong, D.T. \& King, E.R. (1971) Uterine progesterone metabolism and progestational response: effects of estrogens and prolactin. Endocrinology 89, 191197.

Arthur, A.T. \& Daniel, J.C., Jr (1972) Progesterone regulation of blastokinin production and maintenance of rabbit blastocysts transferred into uteri of castrate recipients. Fert. Steril. 23, 115-122.

Bartke, A., Hafiez, A., Bex, F.J. \& Dalterio, S. (1978) Hormonal interactions in regulation of androgen secretion. Biol. Reprod. 18, 44-54.

Bullock, D.W. \& Willen, G.F. (1974) Regulation of a specific uterine protein by estrogen and progesterone in ovariectomized rabbits. Proc. Soc. exp. Biol. Med. 146, 294-298.

Bullock, D.W., Woo, S.L.C. \& O'Malley, B.W. (1976) Uteroglobin messenger RNA: translation in vitro. Biol. Reprod. 15, 435-443.
Burton, K. (1956) A study of the conditions and mechanisms of the diphenylamine reaction for the colorimetric estimation of deoxyribonucleic acid. Biochem. J. 62, 315-323.

Challis, J.R.G., Davies, I.J. \& Ryan, K.J. (1973) The concentrations of progesterone, estrone and estradiol-17 $\beta$ in the plasma of pregnant rabbits. Endocrinology 93, 971-976.

Channing, C.P. \& Evans, V.W. (1982) Stimulatory effect of ovine prolactin upon cultured porcine granulosa cell secretion of inhibitory activity of oocyte maturation. Endocrinology 111, 1746-1748.

Chen, T.J. \& Leavitt, W.W. (1979) Nuclear progesterone receptor in hamster uterus: measurement by $\left({ }^{3} \mathrm{H}\right)$ progesterone exchange during the estrous cycle. Endocrinology 104, 1588-1597.

Chilton, B.S. \& Key, T.L. (1984) Temporal effects of estradiol on progesterone receptor and glycoprotein synthesis in the epithelial-stromal complex of the rabbit endocervix. Biol. Reprod. 30, 231-238.

Chilton, B.S., Nicosia, S.V. \& Lyttle, C.R. (1982) Cytosol and nuclear estrogen and progesterone receptors in the rabbit endocervix. J. Steroid Biochem. 17, 363369.

Danforth, D.N., Jr, Tamarkin, L. \& Lippman, M.E. (1981) Melatonin-induced alterations in estrogen- 
receptor activity in MCF-7 human breast cancer cells. Endocrinology 108, Suppl. 660a, Abstr.

Danforth, D.N., Jr, Tamarkin, L., Do, R. \& Lippman, M.E. (1983) Melatonin-induced increase in cytoplasmic estrogen receptor activity in hamster uteri. Endocrinology 113, 81-85.

Daniel, J.C., Jr (1980) Factors influencing uteroglobin synthesis. In Steroid Induced Uterine Proteins, pp. 87103. Ed. M. Beato. Elsevier/North Holland Biomedical Press, Amsterdam.

Daniel, J.C. \& Booher, C.B. (1977) Synthesis of the rabbit uterine protein, blastokinin: changes in rate prior to implantation. J. Tenn. Acad. Sci. 52, 35-37.

Daniel, J.C., Jr, Jetton, A.E. \& Chilton, B.A. (1983) Evidence of prolactin regulation in rabbit uterine endometrium. J. Cell Biol. 97, 156a, Abstr.

Dunbar, B.S. \& Daniel, J.C., Jr (1979) High molecular weight components of rabbit uterine fluids. Biol. Reprod. 21, 723-733.

Elger, W. \& Beier, H.M. (1982) Pharmacological aspects of early pregnancy and contraception. In Proteins and Steroids in Early Pregnancy, pp. 311-334. Eds. H. M. Beier \& P. Karlson. Springer-Verlag, Berlin.

Evans, R.W., Chen, T.J., Henry, W.J., III \& Leavitt, W.W. (1980) Progesterone regulation of estrogen receptor in the hamster uterus during the estrous cycle. Endocrinology 107, 383-390.

Fridlanski, F. \& Milgrom, E. (1976) Interaction of uteroglobin with progesterone, $5 \alpha$ pregnane-3,20-dione and estrogens. Endocrinology 99, 1244-1251.

Garola, R.E. \& McGuire, W.L. (1977) An improved assay for nuclear estrogen receptor in experimental and human breast cancer. Cancer Res. 37, 3333-3337.

Garola, R.E. \& McGuire, W.L. (1978) A hydroxylapatite micromethod for measuring estrogen receptor in human breast cancer. Cancer Res. 38, 2216-2220.

Harrington, F.E. \& Rothermel, J.D. (1977) Daily changes in peripheral plasma progesterone concentrations in pregnant and pseudopregnant rabbits. Life Sci. 20, $1333-1340$.

Hartman, H.A. (1974) The fetus in experimental teratology. In The Biology of the Laboratory Rabbit, pp. 91153. Eds. S. H. Weisbroth, R. E. Flatt \& A. L. Kraus. Academic Press, New York.

Haug, E. (1979) Progesterone suppression of estrogenstimulated prolactin secretion and estrogen receptor levels in rat pituitary cells. Endocrinology 104, 429 431.

Holt, J.A., Lorincz, M.A. \& Lyttle, C.R. (1981) Estrogen receptor in rabbit ovaries and effects of antiestrogen on progesterone production. Endocrinology 108, $2308-2315$

Isotalo, H., Isomaa, V. \& Janne, O. (1981) Replenishment and properties of cytosol progesterone receptor in rabbit uterus after multiple progesterone administrations. Endocrinology 108, 868-873.

Itzhaki, R.F. \& Gill, D.M. (1964) A micro-biuret method for estimating protein. Analyt. Biochem. 9, 401-410.

Janne, O.A. (1981) Progesterone action in mammalian uterus. Acta obstet. gynaec. scand., Suppl. 101, 11-16.

Joseph, M.M. \& Mubako, H.B. (1975) Extraovarian effect of prolactin on the traumatized uterus in the rat. J. Reprod. Fert. 45, 413-414.

Kao, L.W.L. \& Bullock, D.W. (1981) Rates of uteroglobin synthesis by endometrial explants from different days of early pregnancy in the rabbit. Biol. Reprod. 25, 820-824.

Kennedy, T.G. \& Armstrong, D.T. (1972) Extra-ovarian action of prolactin in the regulation of uterine lumen fluid accumulation in rats. Endocrinology 90, 15031509.

Kopu, H.T., Kokkonen, E.K.T. \& Janne, O.A. (1981) Acute antiprogestational action of estradiol in the rabbit uterus. Endocrinology 109, 1479-1483.

Leung, B.S. \& Sasaki, G.H. (1973) Prolactin and progesterone effect on specific estradiol binding in uterine and mammary tissues in vitro. Biochem. Biophys. Res. Commun. 55, 1180-1187.

Loosefelt, H., Fridlanski, F., Savouret, J.F., Atger, M. \& Milgrom, E. (1981) Mechanism of action of progesterone in the rabbit endometrium. J. biol. Chem. 256, 3465-3470.

Lowry, O.H., Rosebrough, N.H., Farr, A.L. \& Randall, R.J. (1951) Protein measurement with the folinphenol reagent. J. biol. Chem. 193, 265-275.

Martinet, L., Allais, C. \& Allain, D. (1981) The role of prolactin and $\mathbf{L H}$ in luteal function and blastocyst growth in mink (Mustela vison). J. Reprod. Fert., Suppl. 29, 119-130.

Mathur, R.S., Landgrebe, S. \& Williamson, H.O. (1980) Progesterone, 17-hydroxyprogesterone, estradiol, and estriol in late pregnancy and labor. Am.J. Obstet. Gynec. 136, 25-27.

McNeilly, A.S. \& Friesen, H.G. (1978) Prolactin during pregnancy and lactation in the rabbit. Endocrinology 102, 1548-1554.

Murphy, B.D., Concannon, P.W., Travis, H.F. \& Hansel, W. (1981) Prolactin: the hypophyseal factor that terminates embryonic diapause in mink. Biol. Reprod. 25, 487-491.

Neulen, J., Beato, M. \& Beier, H.M. (1982) Cytosol and nuclear progesterone-receptor concentrations in the rabbit endometrium during early pseudopregnancy under different treatments with estradiol and progesterone. Molec. cell. Endocr. 25, 183-191.

Oudin, J. (1952) Specific precipitation in gels and its application to immunochemical analysis. In Methods in Medical Research, Vol. 4, pp. 335-378. Ed. A. C. Corcoran. Year Book Publishers, Chicago.

Popp, R.A., Foresman, K.R., Wise, L.D. \& Daniel, J.C., Jr (1978) Amino acid sequence of a progesteronebinding protein. Proc. natn. Acad. Sci. U.S.A. 75, 5516-5519.

Posner, B.I., Kelly, P.A., Shiu, R.P.C. \& Friesen, H.G. (1974) Studies of insulin, growth hormone and prolactin binding: tissue distribution, species variation and characterization. Endocrinology 95, 521531.

Rahman, S.S., Billiar, R.B. \& Little, B. (1975) Induction of uteroglobin in rabbits by progestogens, estradiol$17 \beta$ and ACTH. Biol. Reprod. 12, 305-314.

Rose, J., Stormshak, F., Adair, J. \& Oldfield, J.E. (1983) Prolactin binding sites in the uterus of the mink. Molec. cell. Endocr. 31, 131-139.

Rosenfeld, M.G., Amara, S.G., Birnberg, N.C., Mermod, J.J., Murdock, G.H. \& Evans, R.M. (1983) Calcitonin, prolactin and growth hormone gene expression as model systems for the characterization of neuroendocrine regulation. Recent Prog. Horm. Res. 39, 305-351. 
Saiduddin, S. \& Zassenhaus, H.P. (1977) Effect of prolactin on specific oestradiol receptors in the rat uterus. J. Endocr. 72, 101-102.

Sartor, P., Slabaugh, M., Sakai, D. \& Gorski, J. (1983) Estrogen receptor development in the absence of growth hormone and prolactin: studies in dwarf mice. Molec. cell. Endocr. 29, 91-99.

Scatchard, G. (1949) The attractions of proteins for small molecules and ions. Ann. N.Y. Acad. Sci.51, 660-672.

Torkkeli, T. (1980) Early changes in rabbit uterine progesterone receptor concentrations and uteroglobin synthesis after progesterone administration. Biochem. Biophys. Res. Commun. 97, 559-565.
Urzua, M.A., Stambaugh, R., Flickinger, G. \& Mastroianni, L. (1970) Uterine and oviduct fluid protein patterns in the rabbit before and after ovulation. Fert. Steril. 21, 860-865.

Williams, G.H., Hammond, J.M., Wiesz, J. \& Mortel, R. (1978) Binding sites for lactogenic hormone in the rat uterus. Biol. Reprod. 18, 697-706.

Young, C.E., Smith, R.G. \& Bullock, D.W. (1981) Uteroglobin mRNA and levels of nuclear progesterone receptor in endometrium. Molec. cell. Endocr. 22, $105-112$.

Received 23 February 1984 